\title{
Paradoxes of the Collective Perception of Russians Regarding Local Self-Government: A Cultural Historical Analysis
}

\author{
Elena Leonidovna Shilkina \\ Doctor of Sociology, Professor of the "Public and Municipal Administration" \\ Department at Rostov State Transport University, Rostov-on-Don, Russia
}

Tatyana Aleksandrovna Marchenko

Doctor of Sociology, professor of the "Department of Applied Sociology "at the Southern Federal University, Rostov-on-Don, Russia

\section{Olga Borisovna Podolskaya}

Sociology Candidate, associate professor of the "Social Technologies" Department of the Institute of Services and Entrepreneurship (branch of) Don State Technical University, Shakhty, Rostov, Russia

Doi:10.5901/mjss.2015.v6n4s4p196

\section{Abstract}

In this article, the origin of Russian local self-government is analyzed, in which its characteristics and stages are identified through historical-cultural retrospective. The Russian collective perception of local self-government is embodied in Russian social cultural historical experience. We attempt to explain the paradox of Russian collective perception of local selfgovernment, which involves the following dichotomy: high approval ratings of democratic ideas of local self-government and the low citizen activity of modern Russians in answering questions of national importance through the prism of historical cultural analysis.

Keywords: local self-government, state, origin, collective perception, institutionalization

\section{Introduction}

Modern Russia is undergoing the process of establishing democratic authorities, in which local self-government plays an important role. Undoubtedly, in order to successfully realize this process, the support and active participation of local citizens is required.

Current national self-government research is being undertaken with the primary focus on electoral tendencies (Gogoleva, 2012), but it does practically nothing to examine the origin of the establishment of the population's collective perception in this sphere. At the same time existing research of the Russian collective perception (Shilkina, Marchenko, and Nekrasov, 2014) has revealed this paradoxical fact: the democratic ideas of local self-government has a rather high approval rating despite the low appraisal of self-government bodies and weak civil activity of local community members regarding local self-government, which testifies to the appropriate level of its legitimacy.

To understand this dichotomy, in our opinion, one must analyze local self-government and try to trace the formation of collective perception in a historical and socio-cultural retrospective.

It should be noted that the problem of forming local self-governing bodies is inextricably linked to the emergent properties of power ancestral traits in a given period of history of the country. The peculiarities of government agencies in particular historical periods determine the forms of organization and implementation of self-government and the level of legitimacy.

\section{The Origin of Local Self-Government}

\subsection{Self-Government Before the Creation of the Single Moscow State.}

The first famous self-government institution in Russia is the Slavic community, in which the principle of direct democracy 
existed. In accordance with the traditions of Slavic communal tribes, all vitally important questions regarding life were decided at a community meeting (Veche), in which the leader of every house took part.

The German sociologist F. Tönnies while researching the development of European society in his work "Gemeinschaft und Gesellschaft "brought to light a number of contradictions between community and society. In contrast to the community, "society is associated with a big city, a nation, convention, politics, public opinion, business operations, industry and science" (Tönnies, 2002). The Slavic community did not experience this contradiction, as throughout its thousand-year existence, up to the Stolypin reforms of the early XX century, it developed in parallel with the transformations of statehood.

In studying the history of Russian self-government, one cannot ignore the Novgorod Republic. The leadership of Novgorod was implemented by the Veche bodies system to answer the socio-economical, military, political, judicial and administrative questions. This system included urban Veches, meetings (skhods) of parties, kontsy (ends) and ulitsy (streets). The leaders of every household, who were usually adult men, could participate in the Veche.

In Kliuchevskii's opinion, "the very composition of the Veche did not allow for any proper discussion or voting" (Kliuchevskii, 2005). There was no clear way of voting during the Veche meetings, there was, however, anarchy, internal strife, noise and shouting.

Nevertheless, the Novgorod form of self-government, doubtlessly was a bright example of direct democracy. In addition, despite the fact that the Novgorod Republic was an independent state, the Veche system acted as both a governing body and a local self-governing body.

In our opinion, features of Russian self-governance originate not only from the Slavic community and the traditions of Novgorod, as we stated earlier, but also from traditional management systems of the Tatar-Mongol Yoke period, although even the thought of self-government in this period of time seems absurd.

The Golden Horde's system of state control included elements of local self-government. The authorities relied on local knyazes (princes) and provided them with extensive autonomy for issues within the principality. To maintain the favor of the Khan, local rulers had to acknowledge his supremacy, pay tribute and supply soldiers to the Mongol army. But overall, local rights, economics, and other spheres were not subject to the influence of the Khan's power.

In this way, we can imagine that elements of local self-government existed even in the Tatar-Mongol Yoke period. Moreover, this period formed certain features of Russian local self-government. The main feature being that local selfgovernments, through the prince, could act as an intermediary, imposing sanctions of higher administration. Collective perception was influenced by the prince's inability to protect the population from extortion in the form of tribute, losing sons who were recruited into the Mongol-Tatar army, as well as a trip where the prince bowed to the Golden Horde. All of this contributes to the perceived lack of authority of local powers as a guarantor of freedom and justice.

\subsection{Local Self-Government during the Formation of the Absolute Monarch}

Further development is associated with the formation of the Russian absolute monarchy, the beginnings of which are generally debatable, under either Ivan Kalita, Ivan III, or Ivan IV (the Terrible). But clearly it culminates under Peter the Great, when unification and the centralization of power occurs against the backdrop of powerful social and political control, which has generated a new public understanding of the central government's value as a guarantor of the preservation of the state, and at the same time the local powers' authority falls (Makarenko, 1998).

The role of local self-governments in Russia acting as an intermediary, imposing sanctions of a higher administration is clearly demonstrated in the era of Ivan IV, when state power strengthened and autocratic rule began to take form, thus proving the aforementioned thesis. In this period, Russia became an estate monarchy with protected selfgoverning components: Zemsky Sobor, Zemstvo and provincial self-governments. The specifics of the processes that formed the Russian absolute monarchy should be noted. Whereas absolutism in Western Europe was formed on the basis of balance between the emerging bourgeoisie and the feudal lords, the law of «balanced classes» did not apply to Russia. Absolute government was created not with the support of the bourgeoisie, but with officials of various ranks in public service.

In the middle of the XVI century, independent functions of local self-government were rapidly shrinking, despite the fact that Ivan the Terrible, per tradition, still convened representatives of local communities in the Zemsky Sobor. However, their main responsibility was collecting funds for the treasury. Officials were obliged to carry out the social and political oversight of the local community's heads, which ended up becoming a form of accusation. As a reward, the informer received a portion of the confiscated property.

Thus, the second historical feature of self-government in Russia can be identified as a lack of consideration for social stratification processes by the higher authorities, and therefore a lack of support from broad social strata and the 
practice of forceful social-political control.

\subsection{Local Self-Government in Imperial Russia}

Peter I only started reforming local self-government using a Western model towards the end of his reign. Govenorates (guberniyas) were divided into provinces, which were divided into districts. At the head of these provinces and districts were appointed government officials. However Peter I did not live to put this reform into practice. Nevertheless, his transformation of the Russian government system indirectly influenced the implementation of the authority in the localities. This reform led to even greater centralization of the administrative system and bureaucratization nationwide (Marx, 1980). The questions of education, charity, medicine, promotion of trade and industry were entrusted to the bureaucracy.

Significant changes in the self-government's development took place under Catherine the Great. According to the first part of "The Statute on the Administration of the Guberniyas of the All Russian Empire," published on November 7 , 1775, the Empire was divided into large local guberniyas and guberniyas into even smaller uyezds (Danilevskii, 1991).

The Empress wanted to employ the Western principle of decentralization of authority and create self-governing bodies in the localities. «The Charter to the Cities» established a class wide «civil society» for the first time in Russian cities.

Elected bodies were first introduced to cities: the State Duma, the State Council, which was headed by the mayor, who was elected in accordance with the property census. Their authority extended to the long-standing matters of local self-government: road conditions, wells, bridges, trade organization, sanitation of the city, creating homes for troubled children, hospices, etc.

«Charter to the Nobles» introduced the noble institution of local self-government in the form of guberniyas and uyezds noble assemblies. In accordance with its name, only nobility could be elected into them. Nevertheless, it was undoubtedly a form of local self-governance, as their purview included the livelihood organizations in the guberniyas and uyezds.

In this way, these two documents mark the reform of local self-government in two areas, including both the cities and the Russian villages. However, the regulatory role of these self-government bodies was, in practice, much narrower than planned.

\subsection{Zemstvo and Municipal Self-Government after the Reforms of Alexander II}

The bourgeois reforms of Alexander II, which started from the abolition of serfdom in 1861, marked a significant step in the history of Russia and Russian local self-government.

Based on the Zemstvo and municipal provisions of 1864 Zemstvo and municipal authority was legislatively separated from the state power.

Representatives of the peasantry were able to participate in the work of local self-government bodies for the first time since 1613 as a result of these reforms. Although the participation of peasants was limited, as the elections were organized into two blocs: first, they would choose their electors who would in turn choose the members of the council. This system ensured that the nobility would be predominant in the Zemstvo governing bodies (Helli, 1998).

Zemstvo institutions dealt with property management, charity, road and bridge maintenance, water supply, the development of local trade and industry, education and health care, insurance, statistics, veterinary medicine, agronomy and other things. In other words, they carried out all the tasks relevant to the livelihood of the population in their administrative district.

Zemstvos were also responsible for the construction of schools and hospitals, appealing to the local population. Zemstvo activities brought veterinary and agronomic expertise to Russian villages, as well as professional medical assistance (including psychiatric care).

The facilities and funds were not state owned, but generated from collecting Zemstvo feudal homage.

Undoubtedly, Zemstvo's activities and those of the urban self-government contributed to the democratization of local self-government, the formation of a public civic culture, as well as humanity and the promotion of universal human values. It became a catalyst for political and publication activity of the Zemstvo movement's leaders (whose ideas were subsequently adopted by Socialist Revolutionary Party ideologists), as opposed to the official doctrine of the Russian state. This lead, to some extent, to the counter reforms of the 1880s, which limited the Zemstvo self-government's authority.

Therefore, despite the fact that the Zemstvo and urban authorities were separated from State power as of 1864, 
and the authority of the local self-government was quite broad, the role of oversight still resided with the central government and Alexander III reforms significantly curtailed the independence of urban and rural local self-governments.

\subsection{Soviet Self-Government}

The 1917 Revolution radically changed the political power structure and the perception of the state, including the role of local self-governments.

Soviets, arising spontaneously to organize armed resistance of workers and soldiers during the 1905 Revolution became the innovative new way to organize government powers in the localities. The role and place of the Soviets in the political system, according to V.I. Lenin's theory, was contingent on Bolshevik vision of structuring working class sociopolitical organizations and a general understanding of democracy.

Initially, the Soviets were informal organizations without well-defined functions (for example, the Petrograd Soviet, who arose spontaneously in the Putilov factory in February 1917).

Local Soviets - the Soviets of Workers' and Soldiers' Deputies and Soviets of Peasants' and Cossacks' Deputies - (or as we would call them today «urban» and «rural») were considered as the source of authority, and the Congress of Soviets' decisions emerged from the work of Soviets on all levels.

Initially, the Soviets were indeed the most democratic form of local self-government in the history of the Russian state.

The Soviets' actions encompassed a majority of citizens. Every person who was a part of the «workers» category could vote or be elected to these bodies. Representatives of the bourgeois class were deprived of such opportunities and as of 1918 so were members of the Menshevik and Socialist Revolutionary parties.

It should be noted that this opened up a new channel of social mobility. Many of the first Soviets' leaders subsequently became professional politicians of the Soviet Russia.

Interestingly, in the first months of Soviet power the Zemstvos and the city Dumas continued their work to ensure the improvement and operation of public services, challenging the authority of the local Soviets: the Duma in the cities and the Zemstvos in the villages. This was due to the fact that the previous local power had earned the trust of their people. The Soviet form of government could not oust the Duma and the Zemstvos as easily and quickly as they had the central government because of this factor. However, the Soviets gradually took on provisional powers and administrative decision making tasks of local importance.

The 1918 Constitution declared that power belonged to the entire working population of the country in the form of the Soviets: urban and rural, regional and territorial, and thus finished the pyramid with the Russian Central Executive Committee.

However, the implementation of these authorities would, in practice, inevitably led to an increase in bureaucracy and the centralization of power, primarily in the hands of CPSU party leaders (b). The role of local self-government shrank and was gradually transformed became purely perfunctory.

Curiously, this process did not cause any widespread public dissent. This is likely due to the fact that the strong central government has been habitualized in the public collective consciousness throughout the history of Russian statehood and has acquired this emergent quality. So the populace dutifully «believed» in this new power.

It is possible, in our opinion, to explain such a phenomenon with G. Bulmer's definition of "community." This phenomenon does not manifest in a well-established group as it, according to the scientist, emerges in situations where everyday existence or the daily routines of life are disrupted. Public opinion takes on a «central tendency» attitude towards social problems, and the opinions of the majority are not necessarily expressed. «Some certain public opinion is most likely somewhere between a highly emotional and biased viewpoint and an eminently sensible and well considered opinion» (Bloomer, 1994). The national unity lost in the revolution required a replacement, which the Soviet state found in building a «bright new future.»

In light of this, the Soviets, just as the local self-governments from 1917, lost their relevance and were transformed into lower level institutions of the state bureaucracy, as the actual self-governments could not address the community's need for a different sense of unity than that which existed before the revolution.

\subsection{Post-Soviet Self-Government}

In the USSR and in post Soviet Russia, the main authority was and still is concentrated in the central government, including the reallocation of funds to regions.

The current tendency is in the deveopment of local self-government and the construction of its legislative 
framework. The legislative basis for local self-government is laid out in the Constitution and in the law «About General Principles of the Organization of Local Self-Government in the Russian Federation» of October 6, 2003, №131-FZ. This law was amended to clearly delineate the scope of the local self-government, federation subjects and federal authorities.

Despite dramatic changes in the local self-government system, collective perception of the local self-governing bodies are perceived as lower levels of government power, whose activities are determined by state authorities and federal subjects.

As we see it, this can be explained by the Soviet worldview and its traditions, as well as low levels of citizen involvement in political and civic culture and a lack of knowledge with regard to modern Russian legislation.

This form of public representation was also greatly influenced by the fact that real power was actually held by the executive branch, which is often the elite and the bureaucracy, sharing a «sphere» of authoritative functions and powers. This is, beyond a doubt, the fact of the matter, even though the Constitution of the Russian Federation states that «the bearer of sovereignty and the only source of power in the Russian Federation shall be its multinational people. The people shall exercise their power directly, and also through the bodies of state power and local self-government» (Constitution of the Russian Federation).

\section{Analysis of Collective Perception}

Collective perception in various areas, including the government, is formed historically and logically. Historically, collective perception of power, in general, and local self-government specifically, are traditional and deeply rooted in the minds of the people and in their everyday life.

Why, then, was the idea of self-government not established as collective perception? Why do democratic ideas of local self-government have fairly high ratings, when the public doesn't value local self-government activities or participate in the local self-government?

Like any other social institution, local self-government system in Russia went through certain specific stages of institutionalization. It is well known that the first stage in establishing a social institution certain needs must arise. In the case of local self-government, the need, which needs to be addressed, is the various matters of daily life of the local community.

In the next stage resources become available to address these needs. The elected representatives serve as the local self-government's resources.

The third stage is habitualization. People typically become accustomed very quickly when their needs are responded to in a more or less high-quality fashion by those with power delegated to them. This aspect is reflected mostly in social facts, namely, a set of norms, values and rules established and internalized by community members. And this is exactly the step one can consider as the start of the formation of the citizens' collective perception.

The final step is institutionalization, or the formal consolidation of a social institution (Berger and Lukman 1995), which takes place in two areas: laws and regulations (legality), and collective perception (legitimacy).

It should be noted that the accountability of Russian local self-government bodies developed more than its initiative at all stages of its institutionalization. This fact was definitely noticed by the rank and file members of the community, and quite possibly had additional impact on collective perception's formation.

As mentioned above, the process of forming collective perception goes through all the historical stages of local self-governments' formation and development.

Analysis of the origin of local self-government bodies in Russia, through the frame of collective perception, has shown that the origins of democratic values in local self-government are rooted in the Slavic community's traditions. Other ideals have roots in a period where there was no democracy to speak of - the Mongol-Tartar yoke period However, the Mongol's centralized power, the Kahn, was mixed with wide local self-government. For several centuries, Russia's population formed the notion that the Khan was far away, and local authorities were not capable of protecting their own responsibilities. It is exactly here where the fundamental possibility of collective perception of self-government was inserted into the culture, and, at the same time, a lack of satisfaction with its performance.

The peculiarities of the Russian absolute monarch also influenced the formation of collective perception. Centralized government did not use local self-government on a social basis, preferring to rely on the publicly used administrative resources and strict social and political oversight, which is also reflected in collective perception.

In our opinion, Russia's absolute monarchy period leads to a decline in local self-government's authority and, at the same time, an increase in fear, and therefore respect, of the central government. These trends occurred throughout the ensuing history of local self-government. 


\section{Conclusions}

This study has shown that each historical period that we have considered has its own specific features impact the development of local self-government.

The first government institution was the Russian community, which unlike in western traditions, was not antithetical to society but developed in parallel with the state.

The Tartar-Mongol yoke period and system of relationships imposed its particular characteristics on local selfgovernment and the collective perception of central and local power.

Local authorities in Russia are generally the imposers of the higher administrations' sanctions. Exceptions such as Novgorod and Pskov Republics, as well as self-government in marginalized classes of Russian society (dissenters, Cossacks etc.), contributed to the idea that real and positive self-government was possible. A definite contribution to such a system was made by the Zemstvo institutions' experience, which have made a significant contribution to the development of Russian peasantry's civic culture and general «civilization».

An analysis of the origin of local self-government reveals four of its characteristics: a) Local rulers acted as the central government's support and «separated» the state from its citizens; b) The state has not sought to «balance classes» and is not based on a broad social base, but on bureaucracy; c) There was no tradition of taking into account the interest of broad social layers by the authorities in Russian history; d) Social stability in Russia was mainly achieved through powerful social and political oversight in the background without sufficiently clear legal regulation.

These features of local self-government's origin reflect the follow aspects on the populace's collective perception: a) the authority of the government; b) the lack of authority on the part of local powers; c) high approval ratings of democratic values of the power of the people in combination with low civic activity.

In other words, the whole history of local self-government suggests that rulers of the state are stuck in a dichotomy: on the one hand, they have want complete control of power in general and the localities in particular, and on the other hand, they have attempted to follow the Western model in these matters. However, leaders of self-government in the localities, received a fraction of the power, sought to increase it and thus developed separatist tendencies. This usually resulted in the strengthening of state control and the cutting of local self-governing bodies' rights. Local self-government officials were not the only to feel the state's power and control, but also ordinary members of the community, and this also had an impact on the formation of collective perception.

Stratification of these representations, which will continue to layer in the future in our opinion, stipulate that the democratic ideas of local self-governance is ranked high enough in Russian minds, but the attitude towards the local selfgovernment bodies is not as optimistic.

\section{References}

Berger, P., \& Lukman T. (1995). Sotsial'noye konstruirovaniye vlasti [Social construction of the power] (pp. 89-113). Moscow: Medium [in Russian].

Bloomer, G. (1994). Kollektivnoe povedenie. Amerikanskaia Sotsiologicheskaia mysl' [Collective behavior. American sociological thought] (pp. 188-191). Moscow [in Russian].

Constitution of the Russian Federation dated 12.12.1993 [in Russian]

Danilevskii, N.la. (1991). Rossiia i Evropa [Russia and Europe] (pp. 480, 487). Moscow [in Russian].

Gogoleva, V.N. (2012). Uchastie grazhdan v mestnom samoupravlenii v sovremennoi Rossii [Participation of citizens in local selfgovernment in modern Russia]. Tula: Tula State University Publishing [in Russian].

Helli, R. (1998). Serfdom in Russia. Moscow [in Russian].

Kliuchevskii, V.O. (2005). Kurs russkoi istorii [Course of Russian history]. Full lecture course. Lecture 23 (pp. 30). Moscow: OlmaPRESS Education [in Russian].

Makarenko, V.P. (1998). Russkaia vlast' [Russian power] (pp. 158). Rostov-on-Don [in Russian].

Marx, K. (1980). Razoblacheniia diplomaticheskoi istorii XVIII veka [Exposure oft he diplomatic history]. Voprosy istorii - Issues of History, 4, 5. [in Russian].

Shilkina, E.L., Marchenko, T.A., \& Nekrasov, E.N. (2014). Kontsepty teoreticheskoi sotsiologii v issledovanii mestnogo samoupravleniia [Concepts of theoretical sociology in thestudy of local self-government]. Rostov-on-Don: Profpress [in Russian].

Tönnies, F. (2002). Obshchnost' i obshchestvo: osnovnye ponyatiia chistoi sotsiologii [Commonality and society-main concepts of the pure sociology] (pp. 53, Sklyadneva, D.B., Trans.). St. Petersburg VLADIMIR DAL' [in Russian]. 